\title{
HES1 wt Allele
}

National Cancer Institute

\section{Source}

National Cancer Institute. HES1 wt Allele. NCI Thesaurus. Code C84293.

Human HES1 wild-type allele is located in the vicinity of 3q28-q29 and is approximately 2 $\mathrm{kb}$ in length. This allele, which encodes transcription factor HES-1 protein, plays a role in the regulation of transcription. 